MARI UUSKÜLA, URMAS SUTROP (Tallinn-Tartu)

\title{
PRELIMINARY STUDY OF BASIC COLOUR TERMS IN MODERN HUNGARIAN
}

\begin{abstract}
Brent Berlin and Paul Kay, in their seminal work "Basic color terms" (1969), supposed that there are exceptionally 12 (instead of 11) basic colour terms in Hungarian. They argued that there are two basic terms - piros and vörös - for the red region. Our empirical study shows that there are exactly 11 basic colour terms in modern Hungarian. Ranked by the cognitive salience index proposed by U. Sutrop (2001) they are: piros 'red', kék 'blue', zöld 'green', sárga 'yellow', fehér 'white', fekete 'black', lila 'purple', barna 'brown', szürke 'grey', rózsaszin 'pink' and narancssárga 'orange'. Second term for red vörös is not basic in Hungarian. Hungarian encodes the basic colour terms in the universal way.
\end{abstract}

Keywords: Hungarian, basic colour term, empirical study, red.

\section{Introduction}

The basic colour terms are a domain of lexis, empirically relatively well researched in the languages of the world. The intensive research into colour terms was laid foundation to, by Brent Berlin's and Paul Kay's inspiring and much discussion evoking monograph "Basic Color Terms. Their Universality and Evolution" (Berlin, Kay 1969). Subject to this theory the basic colour terms always appear, in every language in a fixed universal sequence, and in the language of a fully evolved colour system (stage VII) they number eleven in total: 'black', 'white', 'red', 'yellow', 'green', 'blue', 'brown', 'grey', 'pink', 'purple', 'orange'. This universalistic evolutionary theory of the emergence of colour terms states that all languages have at least two basic colour terms ('black' and 'white') that correspond to certain criteria of basicness. If a language has three basic colour terms then it has terms for black, white and red; if a language has four basic terms then it has 'black', 'white', 'red' and 'yellow' or 'green'; if a language has five basic terms then it has 'black', 'white', 'red', 'yellow' and 'green', etc. up to eleven basic terms.

In the tradition of $\mathrm{B}$. Berlin and P. Kay, the research of Hungarian colour terms has attracted relatively little attention. This may be accounted for by the fact that B. Berlin and P. Kay already handled the colour terms of the Hungarian language in their aforementioned monograph (1969: 95). 
They asserted basing on tests performed with one subject that in Hungarian there are essentially and exceptionally twelve basic colour terms. In pursuance of their visions, the concept 'red' is encoded by two basic terms - piros and vörös. Those two colour terms have offered most research matter in respect of colour terms of the Hungarian language.

The interest towards those colour terms was incipient already at the end of the 19th century, when a medical scientist István Csapódi published an article "Vörös és piros" (1899). The discussion was picked up and carried further by József Gárdonyi (1920) and a chemist Pál Selényi (1947), who among others attempted to physically determine the colour of the Hungarian piros paprika 'red paprika'. The beginning of the 20th century witnessed the publication of two monographs concerned with Hungarian colour terms (Mátray 1910; Bartha 1937), consummate with the glossary of colour names derived from literary sources. The terms depicting the Hungarian 'red' have caught the fancy also of Slavists and general linguists, e.g. Anna Wierzbicka (1996) and A. E. Moss (1989). The 1990s evidenced separate attempts to research the Hungarian language by means of experimental linguistic-cognitive methods. Robert MacLaury, conjointly with Judit Almási and Zoltán Kövecses released an article in the journal "Semiotica" titled "The Hungarian piros and vörös" (MacLaury, Almási, Kövecses 1997). They used the same method as employed in their tests by B. Berlin and P. Kay (1969). Another experimental study was carried out by Leslie Barratt and Miklós Kontra, with a view to identifying whether the subjects speaking Hungarian as mother tongue perceive and name the colours differently from their homologues (counterpart) speaking English in the USA (Barratt, Kontra 1996). The empirical method of both researches was weak, or else the number of subjects and their selection turned out insufficient. In classical study by B. Berlin and P. Kay, too the use of only one subject is seemingly inadequate. Actually, the subject was an emigrant living in the San Francisco Bay Area in the USA. Furthermore, there occurred some inaccuracies in spelling of the Hungarian colour terms (e.g. the outdated form fejér, which must be spelt fehér 'white'), because the authors referred to a dictionary of Hungarian issued in Cleveland and of dubious authority.

The third experimental research was done by Gábor Kiss and Isabel Forbes; first, they requested 98 subjects aged $15-25$ to put down as many colour terms in Hungarian as they could recall; second, the same subjects had to name things, items or phenomena, which could be used collaterally with the words piros and vörös (Forbes, Kiss 1999; Kiss, Forbes 2001). The outcome of research is of questionable worth, particularly with respect to test of written listing. Unfortunately the authors make no mention to whether they conversed with the subjects about the basic colour terms or whether the survey was spontaneous.

It thence transpires that the Hungarian colour terms have been little studied heretofore, empirically, with sufficient number of subjects and proper methods. Because the method of research of colour terms employed by B. Berlin and P. Kay is very costly and time consuming, we opted for Davies-Corbett' field method, by the use whereof the colour terms of e.g. Estonian, Russian, English and many exotic languages have been studied. For collecting the Hungarian material, this method has never been used. 
Basic colour term is determined in this work in the same vein, as it was by B. Berlin and P. Kay (1969 : 5-7). Basic colour term is a psychologically salient, in the general case a morphologically simple own word, belonging to the same word class with the prototype colour names and which have the same grammatical potential. The main word can be used, on cognitive base level, in all relevant and appropriate situations (Sutrop 2000b; 2002 : 31-42).

The goal of this work is to establish whether Hungarian has 11 basic colour terms or 12 colour terms, the existence whereof was referred to by B. Berlin and P. Kay (1969 : 95). It needs to be verified, too empirically whether the basic term for denoting white in Hungarian is altogether fejér, like the above scientists alleged, and whether the compound colour terms narancssárga 'orange yellow; orange' and rózsaszín 'colour of rose; pink' are basic terms.

For elucidating the basic colour terms of Hungarian, the field method of I. Davies and G. Corbett is used (1994; 1995), the list task whereof has been complemented by the cognitive salience index (Sutrop 2001).

\section{Case study: Hungarian colour terms}

L a $\mathrm{n} g \mathrm{u}$ a g e: Hungarian, Finno-Ugric, Uralic.

Region where data have been collected: Budapest, Hungary.

D a t e s: From October 22 to 31, 2002.

$\mathrm{T}$ h e experi m e $\mathrm{n}$ e r: Mari Uusküla spoke Hungarian with subjects. $\mathrm{S} \mathrm{u} \mathrm{b}$ j e c t s: In Budapest, subjected to interview were 40 men and women, averaging 35.8 years of age. Among subjects were 22 women aged 17-71 (average age 33.05 years) and 18 men aged 11-82 (average age 42.66 years). Among subjects were 5 school students (aged 11-17), 5 senior citizens (aged 61-82), and 13 students (aged 21-30).

The respondents (testees) came from the following locations: Budapest, Csömör, Dunaszerdahely (presently Dunajská Streda in Slovakia), Albertirsa, Miskolc, Szany, Tatabánya, Tápiószentmárton, Hajdúszoboszló, Pannonhalma. One subject came from Transcarpathia. All were native speakers of Hungarian. Among 40 subjects was one bilingual subject, coming from Finnish-Hungarian mixed family. Six people of the subjects had the dialectal background (including the Palóc dialect, the western dialect, etc.), some of them could not name their specific dialect - they just knew they were speaking a little dialectally.

The subjects did not know, until the immediate beginning of the test that the questions referred to the colours and their terms.

C o l o u r vi s i o n: All subjects had normal colour vision. This was verified by use of the The City University Color Vision Test (Fletcher 1980). For that the subject is shown ten black tiles, in the middle whereof is a dot of a certain tone of colour surrounded by four dots of colour of different tone. The interviewee must tell which dot is the most similar to the central one: above, down, right or left. The test makes it possible to diagnose almost all anomalies of colour vision like deuteronopia, protonopia, tritanopia etc. 


\subsection{Methods}

B. Berlin and P. Kay used in their work the colour array basing on Munsell colour system, where every subject has to find the suitable focal point for the respective colour term (the colour tile best fitting the term) and thereafter the whole area befitting the colour term was elucidated (Berlin, Kay 1969 : 5-7). Interviews performed under this method are time consuming and cost incurring.

$\mathrm{Th}$ e $\mathrm{f}$ i e l d $\mathrm{met} \mathrm{h}$ o d. In this work, used is the field method of Ian Davies and Greville Corbett (1994; 1995), when interview with one subject takes 20-40 minutes and comprises two parts: the list task and the colour-naming task.

$\mathrm{T} \mathrm{h}$ e $\mathrm{l}$ is t $\mathrm{ta} \mathrm{s} \mathrm{k}$. In the list task, the subjects are requested to list as many colour names as they can call to mind. In this study, every subject was asked the question: "Kérem, mondjon annyi szint magyarul, amennyit tud" 'Please, recount as many colours in Hungarian, as you know.' All colour terms are recorded in the sequence of naming (cf. Sutrop 2001 : 263-264). After fulfilling the list task the subjects were thanked and they moved to the colour vision task.

$\mathrm{The}$ colour-na ming task. The colour-naming task was performed after the list task and after every colour blindness test. Every subject was shown 65 colour tiles in a random sequence placed on the background of grey cloth and was requested to assign a name to the colour, with each tile. The experimenter asked, indicating every colour tile, the invariable question: "Milyen szinü ez?" 'What colour is that?' Colour tiles were shown in natural daylight, however not in shade or in direct sunlight (colour tiles must not be shown to subjects in artificial light, for instance in electric light). All answers were recorded. After the tests were performed, the subjects were thanked. The colour tiles of thin plywood sized $5 \times 5 \mathrm{~cm}$ are covered with Color Aid Corporation colour papers. The test used the Ostwald's colour system, not that of Munsell.

The Ostwa ld's colour system. In the Ostwald's colour system the main features of colour are colour tone i.e. $\mathrm{h} \mathrm{u}$ e, content of white i.e. $\mathrm{t}$ i $\mathrm{n} \mathrm{t}$ and content of black or blackness i.e. $\mathrm{s} \mathrm{h}$ a d e. The brightness grades of grey scale are also distributed into eight grades subject to tint and black content. Color Aid uses the modification of the Ostwald's colour system, where are 24 chromatic colours - 6 primary colours: Y - yellow, O - orange, $\mathrm{R}$ - red, V - violet, B blue, G - green and their transition tones e.g. YO - yellow-orange, YOY - yellow-orange-yellow. Besides that two extra-system colours Sienna and Rose Red have been used. Every colour tone breaks down into four light variants $\mathrm{T} 1-\mathrm{T} 4$, in which the share of tint increases pro rata, and into three dark variants S1-S3, where the role of black increases.

Co-ordinates CIE of colour tiles used in experiment (lightness, content of red and content of green) are available in the work by I. Davies and G. Corbett (1994: 70-71). 


\section{Colour terms: results and discussion}

As the result of tests 3432 colour names were collected, among them 595 different Hungarian colour names. Referred to different names were all morphological variants (e.g. krémszín 'crème colour' and krémszínú 'crème coloured', drapp 'beige' and drappos 'beigeish') and compound names of different type of connection (e.g. vöröslila 'red-purple' and vöröseslila 'reddish-purple'). The phonetic variants are not treated separately. Notably, as a result of assimilation, in many words the word-end $-s$ has transformed to z-, e.g. kékeszöld [kékezzöld] 'bluish-green'. ${ }^{1}$

\subsection{The list task}

In list task, 40 subjects named altogether 858 colour terms, among which there were 205 different colour names. On average, there were 21.45 colour names per subject. The least number of colour names came to mind of a 24 years old male student (only 9 colour names), 10 colour names was the limit to a 49 years old male banking operator and 36 years old female docent. They did not experience difficulties with giving names to colour tiles.

The most colour names (44) occurred to one 24 years female student, 43 colour names came to the head of one female senior citizen, former singing teacher, and 42 names to a female senior citizen, a former secretary. The most aptitude to recall the colour names among males (31) manifested one 36 years old computer graphic artist, whose daily chore the colours were; 30 names were named, too by a director of 50 . Women cited predominantly more colour names than men.

The first offered colour terms in the list task

Table 1

$\begin{array}{llccc}\text { Term } & \text { Gloss } & \text { Women (22) } & \text { Men (18) } & \text { Total (40) } \\ \text { piros } & \text { red } & 8 & 5 & 13 \\ \text { fekete } & \text { black } & 4 & 3 & 7 \\ \text { kék } & \text { blue } & 1 & 5 & 6 \\ \text { fehér } & \text { white } & 3 & 2 & 5 \\ \text { sárga } & \text { yellow } & 4 & 1 & 5 \\ \text { barna } & \text { brown } & 1 & 0 & 1 \\ \text { bogár-fekete } & \text { bug black } & 1 & 0 & 1 \\ \text { bordó } & \text { bordeaux } & 0 & 1 & 1 \\ \text { szivárvány-kék } & \text { rainbow blue } & 0 & 1 & 1\end{array}$

Table 1 presents all colour terms taking precedence over those subsequently named. Most frequently the first mentioned colour name was piros 'red' (13 times); this holds true for both males and females. To follow were fekete 'black' (7 times), kék 'blue' (6 times), fehér 'white' and sárga 'yellow'

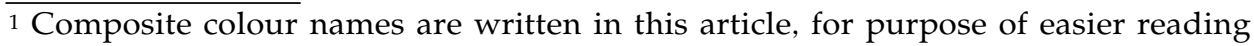
and conveniency with a hyphen '-' unlike the Hungarian literary norm, in order to show the concrete meaning of the composite parts of the compound (there sometimes occur omission of hyphen, i.e. the enclitic variant). The meanings of compounds narancssárga 'orange yellow; orange' and rózsaszín 'colour of the rose; pink' may vary, to the extent of the whole article, i.e.both meanings of those words are supplied collaterally, or only one meaning is provided at a time. 
(both named 4 times). Colour name kék was mentioned as the first more often by males ( 5 times), colour name sárga however by females (4 times). All colour names, which were cited once only, shall be viewed as odd.

List task characterises every offered colour names by two parameters - frequency of the word, i.e. how many subjects offered that word and the mean position, i.e. in which position in sequence that colour name was offered on average. Calculation of those two independent parameters is not adequate for keeping apart the candidates for basic colour term from those who are not candidates for basic colour term, because either of the parameters yields different results. Therefore the frequency and the mean position both are combined into the integral cognitive salience indices (Sutrop 2001 : 266).

Table 2 highlights the colour terms, which have been named by at least 3 subjects. Indicated in the Table 2 is the frequency of colour terms with respective ranks and the mean position of colour names with their respective ranks and there has also been presented the cognitive salience index $\mathrm{S}=\mathrm{F} /(\mathrm{N} \mathrm{mP})$, where $\mathrm{F}$ is the colour name's frequency in list task, $\mathrm{N}$ the number of subjects (in this case 40 ) and $\mathrm{mP}$ the mean position (Sutrop 2001 : 267, 273-274). On the basis of cognitive salience index, we obtain the final ranks of colour terms in list task.

Table 2 reveals that both the frequency and the mean position of the word give different candidates for basic colour term. As per frequency, the most often cited have been the colour terms piros 'red' and fekete 'black' (both 39, the largest possible frequency would have been 40 ). A jump over threshold in frequency occurs after the 12th most frequent colour name bordó 'bordeaux', which has been offered 21 times, and before the 13th most frequent colour name bézs 'beige', which has been offered only 15 times. Following suit are colour terms vilagoskék 'light blue' and drapp 'beige' (frequency 14) and sötetkék 'dark blue' (13). The second Hungarian colour term designating red vörös 'red', offered by B. Berlin and P. Kay as basic colour term, and cited only by 12 out of 40 subjects, shares by frequency the 17th-18th places with the colour term designating light yellow citromsárga 'lemon yellow', what does not run for the status of Hungarian basic colour term status. On the grounds of their spectacular frequency, there are 12 colour names continuing as candidates for basic term status, besides 11 standard names also the colour name bordó.

The mean position also expresses the interest in the colour name, however with decrease of frequency, the weight of that feature drops. One of the most frequently offered colour names piros (39) recurred in the lists predominantly afore, as the third-fourth (the mean position 3.59, rank of position 1), however the colour term fekete of the same frequency will hold, by the rank of mean position (the mean position 6.8 ) as late as the 6th. Colour term kék 'blue' however elevates by the rank of mean position (the mean position 4.1) to the 2 nd place, because it was named at the beginning of lists, although it was done 34 times only. Mean rank of position of colour term halványsárga 'pale yellow' (7th, the mean position 8.333), koromfekete 'pitch black' (8th, the mean position 8.333) and narancs 'orange' (9th, the mean position 8.4) can be explained away by the fact that where they were offered (and the frequency shows that very few subjects did that), it happened at the beginning of lists, as the eighth - ninth. 
Table 2

The most salient colour names in the list task,

where $\mathrm{Fr}$ - frequency, $\mathrm{R}-$ rank, $\mathrm{mP}$ - mean position, $\mathrm{S}$ - salience

\begin{tabular}{|c|c|c|c|c|c|c|c|}
\hline Term & Gloss & Fr & $\mathbf{R}$ & Mp & $\mathbf{R}$ & S & $\mathbf{R}$ \\
\hline piros & red & 39 & 1.5 & 3.59 & 1 & 0.272 & 1 \\
\hline kék & blue & 34 & 7.5 & 4.088 & 2 & 0.208 & 2 \\
\hline zöld & green & 36 & 4.5 & 5 & 4 & 0.180 & 3 \\
\hline sárga & yellow & 35 & 6 & 4.886 & 3 & 0.179 & 4 \\
\hline fehér & white & 37 & 3 & 6.351 & 5 & 0.146 & 5 \\
\hline fekete & black & 39 & 1.5 & 6.795 & 6 & 0.143 & 6 \\
\hline lila & purple & 36 & 4.5 & 8.667 & 10 & 0.104 & 7 \\
\hline barna & brown & 34 & 7.5 & 9.176 & 11 & 0.093 & 8 \\
\hline szürke & grey & 33 & 9 & 10.727 & 14 & 0.077 & 9 \\
\hline rózsa-szín & pink & 29 & 10 & 10.276 & 12 & 0.071 & 10 \\
\hline narancs-sárga & orange & 23 & 11 & 10.438 & 13 & 0.055 & 11 \\
\hline bordó & bordeaux & 21 & 12 & 11.952 & 16 & 0.044 & 12 \\
\hline világos-kék & light blue & 14 & 14.5 & 13.5 & 21 & 0.026 & 13 \\
\hline citrom-sárga & lemon yellow & 12 & 17.5 & 12.333 & 18 & 0.024 & 14 \\
\hline drapp & beige & 14 & 14.5 & 15.643 & 31 & 0.022 & 15 \\
\hline sötét-kék & dark blue & 13 & 16 & 14.538 & 26 & 0.022 & 15 \\
\hline bézs & beige & 15 & 13 & 16.8 & 38 & 0.022 & 15 \\
\hline okker & ochre & 9 & 21 & 11 & 15 & 0.02 & 18 \\
\hline vörös & red & 12 & 17.5 & 15 & 29 & 0.019 & 19 \\
\hline okker-sárga & ochre yellow & 10 & 19.5 & 13.5 & 22 & 0.019 & 19 \\
\hline arany & gold & 10 & 19.5 & 16.7 & 37 & 0.015 & 21 \\
\hline narancs & orange & 5 & 29 & 8.4 & 9 & 0.015 & 21 \\
\hline bibor & scarlet & 7 & 24.5 & 12.714 & 20 & 0.014 & 23 \\
\hline ezüst & silver & 9 & 21 & 17.111 & 41 & 0.013 & 24 \\
\hline hupi-kék & schrill blue & 7 & 24.5 & 14 & 24 & 0.013 & 24 \\
\hline méreg-zöld & poison green & 9 & 21 & 18.333 & 47 & 0.012 & 26 \\
\hline fü-zöld & grass green & 8 & 24 & 18.75 & 48 & 0.011 & 27 \\
\hline király-kék & royal blue & 9 & 21 & 21 & 51 & 0.011 & 27 \\
\hline türkiz-kék & turquoise blue & 5 & 29 & 12 & 17 & 0.01 & 29 \\
\hline türkiz & turquoise & 6 & 25 & 14.833 & 27 & 0.01 & 29 \\
\hline ciklámen & cyclamen & 5 & 29 & 12.6 & 19 & 0.01 & 29 \\
\hline világos-zöld & light green & 6 & 25 & 15.166 & 28 & 0.01 & 29 \\
\hline hó-fehér & snow white & 6 & 25 & 16.5 & 34 & 0.009 & 33 \\
\hline halvány-sárga & pale yellow & 3 & 43 & 8.333 & 7 & 0.009 & 33 \\
\hline korom-fekete & pitch black & 3 & 43 & 8.333 & 8 & 0.009 & 33 \\
\hline khaki & khaki & 6 & 25 & 17.333 & 43 & 0.009 & 33 \\
\hline vaj-szín & butter colour & 5 & 29 & 17 & 39 & 0.007 & 37 \\
\hline halvány-kék & pale blue & 4 & 33 & 14.5 & 25 & 0.007 & 37 \\
\hline tört-fehér & broken white & 4 & 33 & 15.5 & 30 & 0.006 & 39 \\
\hline világos-barna & light brown & 4 & 33 & 16 & 32 & 0.006 & 39 \\
\hline mályva-szín & mauve coloured & 4 & 33 & 16.5 & 35 & 0.006 & 39 \\
\hline szürkés-kék & greish blue & 4 & 33 & 17 & 40 & 0.006 & 39 \\
\hline tenger-kék & sea blue & 4 & 33 & 17.25 & 42 & 0.006 & 39 \\
\hline sötét-zöld & dark green & 4 & 33 & 17.75 & 45 & 0.006 & 39 \\
\hline azur-kék & azure blue & 3 & 43 & 13.666 & 23 & 0.005 & 45 \\
\hline ég-szín-kék & sky-coloured blue & 4 & 33 & 18.25 & 46 & 0.005 & 45 \\
\hline
\end{tabular}




$\begin{array}{llrlllll}\text { Term } & \text { Gloss } & \text { Fr } & \mathbf{R} & \mathbf{M p} & \mathbf{R} & \mathbf{S} & \mathbf{R} \\ \text { encián-kék } & \text { gentian blue } & 3 & 43 & 16 & 33 & 0.005 & \mathbf{4 5} \\ \text { ibolya-kék } & \text { viola blue } & 4 & 33 & 21.5 & 52 & 0.005 & \mathbf{4 5} \\ \text { olaj-zöld } & \text { oil green } & 3 & 43 & 16.666 & 36 & 0.005 & \mathbf{4 5} \\ \text { sötét-barna } & \text { dark brown } & 4 & 33 & 22.25 & 53 & 0.004 & \mathbf{5 0} \\ \text { mályva } & \text { mauve } & 3 & 43 & 17.666 & 44 & 0.004 & \mathbf{5 0} \\ \text { halvány-lila } & \text { pale purple } & 3 & 43 & 20 & 49 & 0.004 & \mathbf{5 0} \\ \text { tüz-piros } & \text { fire red } & 3 & 43 & 20 & 50 & 0.004 & \mathbf{5 0} \\ \text { orgona-lila } & \text { lilac purple } & 3 & 43 & 25 & 54 & 0.003 & \mathbf{5 4} \\ \text { bronz } & \text { bronze } & 3 & 43 & 25.333 & 55 & 0.003 & \mathbf{5 4} \\ \text { moha-zöld } & \text { moss green } & 3 & 43 & 28.333 & 56 & 0.003 & \mathbf{5 4}\end{array}$

Pursuant to the mean position, running for the basic colour term status are only 6 colour names (the mean position $\mathrm{mP}<8$ ): piros, kék, sárga, zöld, fehér and fekete, of which only four first ones can boast the mean position $\mathrm{mP}<6$.

For getting cognitive salience index (S) we can amalgamate the results of frequency and mean position. Just like we did with frequency, we will observe when the numerical crossing of the threshold occurs. The numerical crossover can be noticed after the first colour name piros (cognitive salience index 0.272, with the second colour names kék 0.208). Appreciably, in evidence with colour name piros is the psychologically most salient colour name in Hungarian. In Russian and Estonian the most salient names are respectively синий 'blue' and sinine 'blue' (Davies, Corbett 1994 : 73; Sutrop 2000 : 149). Thereafter, in evidence is numerical shrinking step by step until colour name bordó (cognitive salience index 0.44). The largest leap can be ascertained after colour name bordó, at the colour name világoskék 'light blue', which can no longer considered candidate for basic colour term.

In list task, the colour term frequency i.e. how many times the colour name was offered, was used multiple times (it testifies to the adherence to the idiolects of the subjects), as well as the mean position (testifies to the psychological salience, including occurrence of colour terms at the beginning of lists) and in amalgamating those parameters, the cognitive salience index was calculated. The candidates for basic colour term, under list task are 12 most frequent colour names: 11 standard basic colour terms piros, kék, zöld, sárga, fehér, fekete, lila, barna, szürke, rózsaszín and narancssárga and in addition bordó.

\subsection{The colour-naming task}

In the colour-naming task, from $2600(40 \times 65)$ possible one obtained 2574 answers. Different expressions numbered 520. In 26 cases one could not name the colour. Men had more trouble than women with giving names to colour tiles. In 5 cases one failed to give the name of colour to tile ORO-T3, in 2 cases to colour tile RVR-S1, in 1 case to colour tile Y-S2, YOY-T4, YOY-S2, YO-T3, OYO-hue, O-S1, ORO-S3, RO-T3, ROR-T3, R-T4, R-S3, RVR-S3, VRV-hue and tile Rose Red. One 23 years old male student majoring in philosophy and sociology failed to name seven out of 65 colour tiles, four tiles out of 65 were too challenging to a 67 years old senior citizen. 
Neither encountered difficulties with list task. Out of 2574 colour words, the subjects named 914 one-root words, the composite colour words of two roots were 1400 (including narancssárga and rózsaszín) and composite colour words of three or four roots were 260 . Hence the compound words numbered 1660 and simple words 914 . The longest compound word in the colour-naming task was világos-narancs-sárgás-rózsa-szín 'light orange pink' (verbatim light-orange-yellowish-rose-coloured).

In the list task and the colour-naming task the subjects offered altogether 3432 colour names. In the list task the subjects offered 76 colour names (including bronz 'bronze' and ezüst 'silver'), which they did not later use in the colour-naming task. In the colour-naming task however they offered 399 new colour names, which did not occur in the list task. Altogether two tests yielded 595 different Hungarian colour names.

Presented in the Table 3 are the names most frequently given to every tile together with respective frequencies. To compare with Estonian, cf. the works by Urmas Sutrop (2000a; 2002), for Russian cf. the writing by Ian Davies and Greville Corbett (1994).

Distribution of most frequent terms (hue, tint $=\mathrm{T}$, shadow $=\mathrm{S}$ ) and their corresponding frequencies (Fr) in the tile naming task

\begin{tabular}{|c|c|c|c|c|c|}
\hline Code & Hue & $\mathrm{Fr}$ & $\mathrm{T}$ & Fr & $\mathrm{S}$ \\
\hline \multirow[t]{3}{*}{ Y } & sárga 'yellow' & 19 & & & S2 khaki 'khaki' \\
\hline & $\begin{array}{l}\text { citrom-sárga } \\
\text { 'lemon yellow' }\end{array}$ & 13 & & & barna 'brown' \\
\hline & $\begin{array}{l}\text { okker-sárga } \\
\text { 'ochre yellow' }\end{array}$ & 3 & & & $\begin{array}{l}\text { zöldés-barna } \\
\text { 'greenish brown' }\end{array}$ \\
\hline \multirow[t]{3}{*}{ YOY } & sárga 'yellow' & 15 & $\begin{array}{l}\text { T4 vaj-szímú } \\
\text { 'butter coloured' }\end{array}$ & 5 & S2 drapp 'beige' \\
\hline & $\begin{array}{l}\text { narancs-sárga } \\
\text { 'orange' }\end{array}$ & 5 & $\begin{array}{l}\text { vaj-szín } \\
\text { 'butter colour' }\end{array}$ & 4 & \\
\hline & & & sárga 'yellow' & 3 & \\
\hline \multirow[t]{4}{*}{ YO } & $\begin{array}{l}\text { narancs-sárga } \\
\text { 'orange' }\end{array}$ & 19 & T3 sárga 'yellow' & 4 & S3 barna 'brown' \\
\hline & sárga 'yellow' & 6 & $\begin{array}{l}\text { barack-szín } \\
\text { 'apricot colour' }\end{array}$ & 3 & $\begin{array}{l}\text { sötét-barna } \\
\text { 'dark brown' }\end{array}$ \\
\hline & & & bézs 'beige' & 3 & \\
\hline & & & $\begin{array}{l}\text { okker-sárga } \\
\text { 'ochre yellow' }\end{array}$ & 3 & \\
\hline OYO & $\begin{array}{l}\text { narancs-sárga } \\
\text { 'orange' }\end{array}$ & 27 & & & \\
\hline \multirow[t]{5}{*}{$\mathrm{O}$} & $\begin{array}{l}\text { narancs-sárga } \\
\text { 'orange' }\end{array}$ & 16 & & & S1 barna 'brown' \\
\hline & narancs 'orange' & 3 & & & $\begin{array}{l}\text { világos-barna } \\
\text { 'light brown' }\end{array}$ \\
\hline & $\begin{array}{l}\text { rozsda-barna } \\
\text { 'rust brown' }\end{array}$ & 5 & & & \\
\hline & & & & & $\begin{array}{l}\text { S3 sötét-barna } \\
\text { 'dark brown' }\end{array}$ \\
\hline & & & & & barna 'brown' \\
\hline
\end{tabular}




\begin{tabular}{|c|c|c|c|c|c|c|}
\hline Code & Hue & Fr & $\mathrm{T}$ & Fr & $\mathrm{S}$ & Fr \\
\hline \multirow[t]{2}{*}{ ORO } & piros 'red' & 12 & $\begin{array}{l}\text { T3 narancs-sárga } \\
\text { 'orange' }\end{array}$ & 5 & S3 bézs 'beige' & 3 \\
\hline & $\begin{array}{l}\text { narancs-sárga } \\
\text { 'orange' }\end{array}$ & 4 & barack 'apricot' & 3 & & \\
\hline \multirow[t]{3}{*}{$\mathrm{RO}$} & piros 'red' & 28 & T3 rózsa-szín 'pink' & 5 & $\begin{array}{l}\text { S3 sötét-barna } \\
\text { 'dark brown' }\end{array}$ & 23 \\
\hline & $\begin{array}{l}\text { tüz-piros } \\
\text { 'fire red' }\end{array}$ & 2 & & & barna 'brown' & 14 \\
\hline & vörös 'red' & 2 & & & & \\
\hline \multirow[t]{3}{*}{ ROR } & piros 'red' & 21 & T3 rózsa-szín 'pink' & 13 & $\begin{array}{l}\text { S3 világos-rózsa-szín } \\
\text { 'light pink' }\end{array}$ & 3 \\
\hline & $\begin{array}{l}\text { sötét-piros } \\
\text { 'dark red' }\end{array}$ & 4 & $\begin{array}{l}\text { halvámy-rózsa-szín } \\
\text { 'pale pink' }\end{array}$ & 4 & $\begin{array}{l}\text { halvány-rózsa-szín } \\
\text { 'pale pink' }\end{array}$ & \\
\hline & vörös 'red' & 2 & & & & \\
\hline \multirow[t]{2}{*}{$\mathrm{R}$} & bordó 'bordeaux' & 9 & T4 rózsa-szín 'pink' & 17 & $\begin{array}{l}\text { S3 sötét-barna } \\
\text { 'dark brown' }\end{array}$ & 25 \\
\hline & piros 'red' & 8 & $\begin{array}{l}\text { halvámy-rózsa-szín } \\
\text { 'pale pink' }\end{array}$ & 6 & barna 'brown' & 4 \\
\hline \multirow[t]{4}{*}{ RVR } & ciklámen 'cyclamen' & 5 & & & S1 lila 'purple' & 12 \\
\hline & lila 'purple' & 5 & & & bordó 'bordeaux' & 4 \\
\hline & & & & & $\begin{array}{l}\text { S3 rózsa-szín 'pink' } \\
\text { világos-lila } \\
\text { 'light purple' }\end{array}$ & $\begin{array}{l}7 \\
5\end{array}$ \\
\hline & & & $\begin{array}{l}\text { T2 lilás-rózsa-szín } \\
\text { 'purplish pink' }\end{array}$ & 7 & & \\
\hline RV & lila 'purple' & 17 & rózsa-szín 'pink' & 7 & & \\
\hline \multirow[t]{3}{*}{ VRV } & lila 'purple' & 21 & & & $\begin{array}{l}\text { S3 halvány-lila } \\
\text { 'pale purple' }\end{array}$ & 14 \\
\hline & $\begin{array}{l}\text { sötét-lila } \\
\text { 'dark purple' }\end{array}$ & 8 & & & lila 'purple' & 6 \\
\hline & $\begin{array}{l}\text { világos-lila } \\
\text { 'light purple' }\end{array}$ & 6 & & & & \\
\hline \multirow[t]{2}{*}{$\mathrm{V}$} & lila 'purple' & 18 & & & & \\
\hline & $\begin{array}{l}\text { sötét-lila } \\
\text { 'dark purple' }\end{array}$ & 13 & & & & \\
\hline \multirow[t]{3}{*}{ VBV } & lila 'purple' & 19 & T4 lila 'purple' & 10 & & \\
\hline & $\begin{array}{l}\text { sötét-lila } \\
\text { 'dark purple' }\end{array}$ & 11 & $\begin{array}{l}\text { halvány-lila } \\
\text { 'pale purple' }\end{array}$ & 9 & & \\
\hline & & & $\begin{array}{l}\text { világos-lila } \\
\text { 'light purple' }\end{array}$ & 9 & & \\
\hline \multirow[t]{2}{*}{ BV } & kék 'blue' & 6 & & & $\begin{array}{l}\text { S2 sötét-kék } \\
\text { 'dark blue' }\end{array}$ & 12 \\
\hline & $\begin{array}{l}\text { sötét-kék } \\
\text { 'dark blue' }\end{array}$ & 5 & & & $\begin{array}{l}\text { sötét-lila } \\
\text { 'dark purple' }\end{array}$ & 10 \\
\hline \multirow[t]{2}{*}{ BVB } & kék 'blue' & 16 & & & S3 szürke 'grey' & 10 \\
\hline & $\begin{array}{l}\text { sötét-kék } \\
\text { 'dark blue' }\end{array}$ & 10 & & & $\begin{array}{l}\text { kékes-szürke } \\
\text { 'bluish grey' }\end{array}$ & 6 \\
\hline \multirow[t]{2}{*}{ B } & kék 'blue' & 18 & T1 kék 'blue' & 24 & & \\
\hline & $\begin{array}{l}\text { király-kék } \\
\text { 'royal blue' }\end{array}$ & 7 & & & & \\
\hline
\end{tabular}


Mari Uusküla, Urmas Sutrop

\begin{tabular}{|c|c|c|c|c|c|c|}
\hline Code & Hue & Fr & $\mathrm{T}$ & Fr & $\mathrm{S}$ & Fr \\
\hline \multirow[t]{2}{*}{ BGB } & kék 'blue' & 18 & $\begin{array}{l}\text { T3 világos-kék } \\
\text { 'light blue' }\end{array}$ & 15 & & \\
\hline & & & kék 'blue' & 8 & & \\
\hline \multirow[t]{2}{*}{ BG } & $\begin{array}{l}\text { kékes-zöld } \\
\text { 'bluish green' }\end{array}$ & 8 & $\begin{array}{l}\text { T1 kékes-zöld } \\
\text { 'bluish green' }\end{array}$ & 7 & S2 zöld 'green' & 7 \\
\hline & $\begin{array}{l}\text { zöldés-kék } \\
\text { 'greenish blue' }\end{array}$ & 7 & $\begin{array}{l}\text { türkiz-kék } \\
\text { 'turquoise blue' }\end{array}$ & 7 & $\begin{array}{l}\text { kékes-zöld } \\
\text { 'bluish green' }\end{array}$ & 6 \\
\hline \multirow[t]{2}{*}{ GBG } & zöld 'green' & 13 & & & S2 türkiz 'turquoise' & 4 \\
\hline & $\begin{array}{l}\text { kékes-zöld } \\
\text { 'bluish green' }\end{array}$ & 5 & & & & \\
\hline \multirow[t]{2}{*}{ G } & zöld 'green' & 25 & & & $\begin{array}{l}\text { S3 sötét-zöld } \\
\text { 'dark green' }\end{array}$ & 12 \\
\hline & $\begin{array}{l}\text { sötét-zöld } \\
\text { 'dark green' }\end{array}$ & 7 & & & $\begin{array}{l}\text { méreg-zöld } \\
\text { 'poison green' }\end{array}$ & 6 \\
\hline \multirow[t]{3}{*}{ GYG } & zöld 'green' & 23 & $\begin{array}{l}\text { T4 világos-zöld } \\
\text { 'light green' }\end{array}$ & 16 & S1 zöld 'green' & 17 \\
\hline & $\begin{array}{l}\text { fü-zöld } \\
\text { 'grass green' }\end{array}$ & 7 & $\begin{array}{l}\text { halvány-zöld } \\
\text { 'pale green' }\end{array}$ & 5 & & \\
\hline & & & zöld 'green' & 5 & & \\
\hline \multirow[t]{2}{*}{ YG } & zöld 'green' & 13 & & & S3 sötét-zöld & 11 \\
\hline & $\begin{array}{l}\text { világos-zöld } \\
\text { 'light green' }\end{array}$ & 13 & & & $\begin{array}{l}\text { olaj-zöld } \\
\text { 'oil green' }\end{array}$ & 6 \\
\hline \multirow[t]{2}{*}{ YGY } & zöld 'green' & 9 & & & $\begin{array}{l}\text { S3 világos-zöld } \\
\text { 'light green' }\end{array}$ & 10 \\
\hline & $\begin{array}{l}\text { világos-zöld } \\
\text { 'light green' }\end{array}$ & 9 & & & $\begin{array}{l}\text { halvány-zöld } \\
\text { 'pale green' }\end{array}$ & 9 \\
\hline
\end{tabular}

Rose Red ciklámen 'cyclamen' 5

lilás-piros 4

'purplish red'

4

rózsa-szín 'pink' 4

sötét-rózsa-szín 4

'dark pink'

Sienna barna 'brown' 10

világos-barna 7

'light brown'

rozsda-barna 5

'rust brown'

WHITE fehér 'white' 23

tört-fehér 4

'broken white'

piszkos-fehér 3

'dirty white'

GRAY-1 világos-szürke 13

'light grey'

szürke 'grey' 9

GRAY-2 szürke 'grey' 15

világos-szürke 14

'light grey' 


$\begin{array}{llr}\text { Code } & \text { Hue } & \text { Fr } \\ \text { GRAY-4 } & \text { szürke 'grey' } & 30 \\ & \text { világos-szürke } & 4 \\ & \text { 'light grey' } & \\ \text { GRAY-6 } & \text { szürke 'grey' } & 17 \\ & \text { sötét-szürke } & 14 \\ & \text { 'dark grey' } & \\ \text { GRAY-8 } & \text { fekete 'black' } & 26 \\ & \text { sötét-szürke } & 3 \\ & \text { 'dark grey' } & \\ \text { BLACK } & \text { fekete 'black' } & 34\end{array}$

Presented in Table 4 are the most frequent names, which were assigned to all colour tiles in the colour-naming task. The names that were offered less than 10 times are not reflected in this Table. To find the candidates for basic colour terms we will again observe the shrinking of frequency. The first major jump occurs after the colour names kék of third frequency, but it is too early. The next larger jump occurs at the colour name fekete, presented in the Table in the 10th place. Hence the threshold of candidacy for basic status of colour names TotalFr (aggregate frequency) $\geq 60$. By aggregate frequency, running for the status of basic term are 10 colour names zöld, lila, kék, szürke, barna, narancssárga, sötétbarna, piros, rózsaszín and fekete. Somewhat unexpectedly, sötétbarna occurred in that row. This deviation can be accounted for by the fact that a large number of subjects have named as many as three tiles (O-S3, RO-S3, R-S3) by the name sötétbarna 'dark brown'. Estonian subjects have named the same colour tiles (RO-S3 and R-S3) with the colour name must 'black' (cf. Sutrop 2000a : 152; 2002 : 78).

Keeping behind the presented aggregate frequency threshold are two actual candidates for basic colour terms fehér 'white' and sárga 'yellow'. Actually in the whole colour-naming task were only 2 colour tiles, which could be assigned the name sárga and one tile, which could be named fehér. Because in case of colour tile $\mathrm{Y}$, in evidence was the relatively intensive light yellow, several subjects named it citromsárga (cf. Table 5). Colour tiles with the code YOY were also dubbed orange. In case of tile WHITE, in evidence was greyish or soiled white and several subjects named it appropriately. In two cases the colour tiles were named világosszürke 'light grey' and in one case halványszürke 'pale grey'. Yet, one light grey tile was twice named white.

The ratio of aggregate frequency of colour names and the number of tiles, which were assigned one name (TotalFr/NoTiles), is in good correlation with the candidates for the status of basic term. The larger the ratio numerically, the higher the probability, that in evidence is the candidate for basic term. It is evident in the Table that a large leap is occurring between colour name fekete and the other names following it - szürke and piros. This may be indicative of low consensus prevailing among the subjects. It may be, also that the subjects were too scarce. In the research by Urmas Sutrop on Estonian the ratios shrink step by step (cf. Sutrop 2000a : 155; 2002 : 84). 
The most frequent terms in the tile naming task

Table 4

\begin{tabular}{|c|c|c|c|c|c|c|}
\hline Term & Gloss & ర్ & $\stackrel{\tilde{J}}{0}$ & ڤ̊ & $\dot{\mathbf{z}}$ & 离 \\
\hline zöld & green & + & 132 & 48 & 15 & 8.25 \\
\hline lila & purple & + & 121 & 21 & 13 & 8.64 \\
\hline kék & blue & + & 107 & 24 & 12 & 8.23 \\
\hline szürke & grey & + & 88 & 30 & 6 & 12.6 \\
\hline barna & brown & + & 86 & 25 & 9 & 8.6 \\
\hline narancs-sárga & orange & + & 83 & 27 & 10 & 7.55 \\
\hline sötét-barna & dark brown & + & 79 & 68 & 7 & 9.87 \\
\hline piros & red & + & 71 & 49 & 5 & 11.8 \\
\hline rózsa-szín & pink & + & 64 & - & 11 & 5.33 \\
\hline fekete & black & + & 60 & 60 & 2 & 30 \\
\hline világos-zöld & light green & + & 52 & - & 8 & 6.5 \\
\hline sárga & yellow & + & 50 & $19^{2}$ & 7 & 7.14 \\
\hline sötét-lila & dark purple & - & 50 & - & 8 & 6.25 \\
\hline sötét-zöld & dark green & + & 38 & - & 6 & 6.33 \\
\hline világos-szürke & light grey & + & 37 & - & 5 & 7.4 \\
\hline halvány-lila & pale purple & + & 31 & - & 8 & 3.88 \\
\hline sötét-kék & dark blue & + & 31 & - & 4 & 7.75 \\
\hline világos-lila & light purple & - & 30 & - & 8 & 3.75 \\
\hline kékes-zöld & bluish green & + & 28 & - & 5 & 5.6 \\
\hline fehér & white & + & 25 & 23 & 2 & 12.5 \\
\hline világos-kék & light blue & + & 25 & - & 6 & 4.17 \\
\hline világos-barna & light brown & + & 23 & - & 8 & 2.88 \\
\hline sötét-rózsa-szín & dark pink & - & 22 & - & 9 & 2.44 \\
\hline halvány-zöld & pale green & + & 21 & - & 4 & 5.25 \\
\hline zöldes-kék & greenish blue & + & 21 & - & 7 & 3 \\
\hline türkiz-kék & turquoise blue & + & 21 & - & 7 & 3 \\
\hline sötét-szürke & dark grey & + & 17 & - & 2 & 8.5 \\
\hline halvány-rózsa-szín & pale pink & - & 16 & - & 6 & 2.67 \\
\hline ciklámen & cyclamen & + & 16 & - & 6 & 2.67 \\
\hline fü-zöld & grass green & + & 15 & - & 5 & 3 \\
\hline okker-sárga & ochre yellow & + & 15 & - & 8 & 1.88 \\
\hline türkiz & turquoise & + & 15 & - & 4 & 3.75 \\
\hline bordó & bordeaux & + & 14 & - & 3 & 4.67 \\
\hline citrom-sárga & lemon yellow & + & 14 & - & 2 & 7 \\
\hline drapp & beige & + & 13 & - & 5 & 2.6 \\
\hline
\end{tabular}

2 In case of colour name sárga dominance frequency has been presented, although DI $\neq 1 / 2$ (i.e. 20), however 19 . This has been made so to calculate the specificity index (SI). 


Term
halvány-szürke
király-kék
lilás-rózsa-szín
mályva
méreg-zöld
püspök-lila
türkiz-zöld
olaj-zöld
rozsda-barna
khaki
piszkos-fehér

Gloss

pale grey

royal blue

purplish pink mauve

poison green

bishop purple

turquoise green

oil green

rust brown

khaki

dirty white
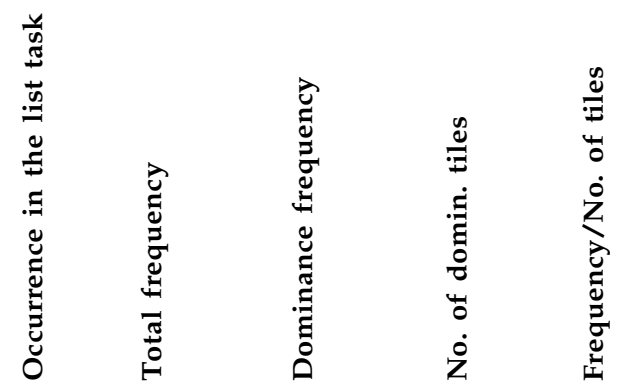

- 13

$+\quad 13$

12
$-\quad 12$

$+\quad 12$

$+\quad 12$

$+\quad 12$

$+\quad 12$

$+\quad 11$

$+\quad 11$
$+\quad 10$

$+\quad 10$

$+\quad 10$

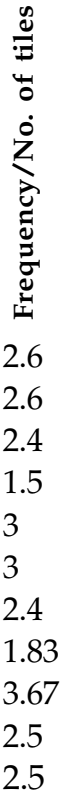

Besides the aggregate frequency and the number of colour tile, Table makes mention of the dominance frequency (DFr). In case of aggregate frequency, all colour names have been taken into account, however the dominance frequency is manifest only with those colour terms, which dominate (i.e. dominance index DI $\geq 1 / 2$ ). Dominance frequency is used for calculation of specificity index (SI) (cf. Table 5).

Table 5

Dominant colour terms in the tile naming task SI - specificity index, DI - dominance index

\begin{tabular}{llccccccc} 
Term & Gloss & SI 1/2 & DI 1/10 & DI 1/4 & DI 1/3 & DI 1/2 & DI 2/3 & DI 3/4 \\
fekete & black & 1.00 & 2 & 2 & 2 & 2 & 1 & 1 \\
fehér & white & 0.92 & 1 & 1 & 1 & 1 & 0 & 0 \\
sötét-barna & dark brown & 0.86 & 4 & 3 & 3 & 3 & 0 & 0 \\
piros & red & 0.69 & 4 & 3 & 2 & 2 & 1 & 0 \\
sárga & yellow & 0.38 & 3 & 2 & 2 & 0 & 0 & 0 \\
zöld & green & 0.36 & 11 & 5 & 5 & 2 & 0 & 0 \\
szürke & grey & 0.34 & 5 & 4 & 4 & 1 & 1 & 1 \\
narancs-sárga & orange & 0.33 & 6 & 3 & 3 & 1 & 1 & 0 \\
barna & brown & 0.29 & 7 & 5 & 3 & 1 & 0 & 0 \\
kék & blue & 0.22 & 8 & 4 & 4 & 1 & 0 & 0 \\
lila & purple & 0.17 & 9 & 6 & 4 & 1 & 0 & 0 \\
rózsa-szín & pink & - & 6 & 2 & 2 & 0 & 0 & 0 \\
sötét-lila & dark purple & - & 5 & 3 & 1 & 0 & 0 & 0 \\
világos-zöld & light green & - & 4 & 3 & 2 & 0 & 0 & 0 \\
világos-szürke & light grey & - & 4 & 2 & 2 & 0 & 0 & 0 \\
sötét-kék & dark blue & - & 4 & 2 & 0 & 0 & 0 & 0 \\
sötét-zöld & dark green & - & 4 & 2 & 0 & 0 & 0 & 0 \\
\multicolumn{1}{r}{$3^{*}$} & & & & & & & & \\
& & & & & & & & 115
\end{tabular}




\begin{tabular}{|c|c|c|c|c|c|c|c|c|}
\hline Term & Gloss & SI $1 / 2$ & DI $1 / 10$ & DI $1 / 4$ & DI $1 / 3$ & DI $1 / 2$ & DI $2 / 3$ & DI $3 / 4$ \\
\hline világos-lila & light purple & - & 4 & 0 & 0 & 0 & 0 & 0 \\
\hline halvány-zöld & pale green & - & 3 & 0 & 0 & 0 & 0 & 0 \\
\hline halvány-lila & pale purple & - & 2 & 1 & 1 & 0 & 0 & 0 \\
\hline bordó & bordeaux & - & 2 & 0 & 0 & 0 & 0 & 0 \\
\hline ciklámen & cyclamen & - & 2 & 0 & 0 & 0 & 0 & 0 \\
\hline halvány-rózsa-szín & pale pink & - & 2 & 0 & 0 & 0 & 0 & 0 \\
\hline halvány-szürke & pale grey & - & 2 & 0 & 0 & 0 & 0 & 0 \\
\hline kékes-zöld & bluish green & - & 2 & 0 & 0 & 0 & 0 & 0 \\
\hline püspök-lila & bishop purple & - & 2 & 0 & 0 & 0 & 0 & 0 \\
\hline türkiz & turquoise & - & 2 & 0 & 0 & 0 & 0 & 0 \\
\hline türkiz-kék & turquoise blue & - & 2 & 0 & 0 & 0 & 0 & 0 \\
\hline világos-barna & light brown & - & 2 & 0 & 0 & 0 & 0 & 0 \\
\hline zöldes-kék & greenish blue & - & 2 & 0 & 0 & 0 & 0 & 0 \\
\hline citrom-sárga & lemon yellow & - & 1 & 1 & 1 & 0 & 0 & 0 \\
\hline sötét-szürke & dark grey & - & 1 & 1 & 1 & 0 & 0 & 0 \\
\hline világos-kék & light blue & - & 1 & 1 & 1 & 0 & 0 & 0 \\
\hline drapp & beige & - & 1 & 0 & 0 & 0 & 0 & 0 \\
\hline khaki & khaki & - & 1 & 0 & 0 & 0 & 0 & 0 \\
\hline király-kék & royal blue & - & 1 & 0 & 0 & 0 & 0 & 0 \\
\hline közép-zöld & medium green & - & 1 & 0 & 0 & 0 & 0 & 0 \\
\hline lilás-kék & purplish blue & - & 1 & 0 & 0 & 0 & 0 & 0 \\
\hline lilás-piros & purplish red & - & 1 & 0 & 0 & 0 & 0 & 0 \\
\hline méreg-zöld & poison green & - & 1 & 0 & 0 & 0 & 0 & 0 \\
\hline olaj-zöld & oil green & - & 1 & 0 & 0 & 0 & 0 & 0 \\
\hline pasztell-zöld & pastel green & - & 1 & 0 & 0 & 0 & 0 & 0 \\
\hline pink & pink & - & 1 & 0 & 0 & 0 & 0 & 0 \\
\hline piszkos-fehér & dirty white & - & 1 & 0 & 0 & 0 & 0 & 0 \\
\hline rozda-barna & rust brown & - & 1 & 0 & 0 & 0 & 0 & 0 \\
\hline sötét-kékes-zöld & dark bluish green & $2-$ & 1 & 0 & 0 & 0 & 0 & 0 \\
\hline sötét-piros & dark red & - & 1 & 0 & 0 & 0 & 0 & 0 \\
\hline sötét-rózsa-szín & dark pink & - & 2 & 0 & 0 & 0 & 0 & 0 \\
\hline tört-fehér & broken white & - & 1 & 0 & 0 & 0 & 0 & 0 \\
\hline türkiz-zöld & turquoise green & - & 1 & 0 & 0 & 0 & 0 & 0 \\
\hline vaj-szín & butter colour & - & 1 & 0 & 0 & 0 & 0 & 0 \\
\hline vaj-szímü & butter coloured & - & 1 & 0 & 0 & 0 & 0 & 0 \\
\hline zöldés-barna & greenish brown & - & 1 & 0 & 0 & 0 & 0 & 0 \\
\hline Dominating & & & 154 & 73 & 61 & 15 & 4 & 2 \\
\hline
\end{tabular}

Table 5 displays the colour names dominating in the colour-naming task, which have been ranked according to specificity index together with dominance index obtained on different values. Also presented in Table is the distribution of dominance.

Colour name is considered dominant, if it has been attributed to one certain colour tile a certain multiple times of the threshold. Dominance index (DI) indicates to how many colour tiles the name superseding the certain threshold has been ascribed. In this work, the dominance index threshold has been calculated as follows: 


$\begin{array}{lccccccc}\text { DI } & 1 / 10 & 1 / 4 & 1 / 3 & 1 / 2 & 2 / 3 & 3 / 4 \\ \text { The threshold for tile } & \geq & 4 & 10 & 13 & 20 & 27 & 30\end{array}$

Specificity index shows the ratio of dominance frequency and aggregate frequency $(\mathrm{SI}=$ DominantFr/TotalFr). Dominance frequency has been presented in Table 4. Specificity index characterises the consensus of opinions. Unlike the ratio of aggregate frequency and number of tiles (TotalFr/NoTiles) the specificity index characterises only the dominating names, because the non-dominating colour terms SI is always equal to zero $(\mathrm{SI}=$ DominantFr $/$ TotalFr $=0 /$ TotalFr $=0$ ). SI is calculated in this work for DI $1 / 2$.

The consensus of opinions is complete in case of fekete $(\mathrm{SI}=1)$. In Russian, the specificity index is 1 for colour name белый 'white' (Davies, Corbett $1994: 79)$. In Estonian, too the consensus was the largest in case of valge 'white' (SI = 0.99) (Sutrop 2000a : 160; $2002: 84-85$ ). The least, however is consensus in case of lila $(\mathrm{SI}=0.17)$. For sárga, an exception has been made and the specificity index calculated, although the tile $\mathrm{Y}$ was called with that name by 19 , not by 20 subjects (i.e. $50 \%$ ). Colour name rózsaszín lacks the specificity index, because one colour tile was called with that name by only 17 subjects. Consequently, the diversity of opinions is large, in case of that colour name.

With the lowest dominance threshold (DI 1/10), 53 different names are dominating in 154 cases, i.e. several colour tiles have been assigned the same name several times. The $25 \%$ threshold (1/4), i.e. when at least 10 subjects have named a certain colour tile with a certain name, are in excess of 21 colour names, which have been given as the name to tiles 73 times. If the consensus of opinions is $50 \%$ (DI 1/2), the colour tiles of the dominating name number only 15 and for the status of basic colour terms, 10 colour names run:fekete, fehér, szürke, sötétbarna, piros, barna, kék, zöld, narancssárga, lila. The threshold DI $1 / 2$ is usually a criterion, so that the colour term could run for the status of basic term. In this work that threshold has not been superseded by the absolutely certain basic colour term's candidate sárga, because as aforementioned, one colour tile was called by that name by 19 , not by 20 subjects $(20=$ DI $1 / 2)$. Stuck behind the threshold is also rózsaszín. If the consensus of opinions is $67 \%$, dominating will be only 4 tiles with four names fekete, piros, szürke and surprisingly, finding itself in this line is also narancssárga. On the level of $75 \%$ consensus (DI 3/4) there are only two colour tiles of dominating name $2-$ fekete and szürke.

Under the dominance, running for the status of basic colour terms are 10 colour names, besides the standard names also sötétbarna. Unjustly falling out is the colour term sárga, we will include it into the colour names. Altogether running, on the basis of dominance frequency and specificity index, for status of basic colour term, 11 colour names: fekete, fehér, szürke, sötétbarna, piros, barna, kék, zöld, narancssárga, lila and sárga. The candidate for basic colour terms rózsaszin will be dropped.

\subsection{The combined analysis}

As a result of the list task and the colour-naming task, running for the status of basic colour terms are 13 colour names, of them 11 standard 
names: piros, kék, zöld, sárga, fehér, fekete, barna, szürke, rózsaszín and narancssárga, 1 composite name sötétbarna and 1 simple colour term bordó. For final analysis we will add also some other colour names like vörös and narancs (recurrent with Berlin and Kay as basic colour terms of Hungarian), citromsárga, világoskék and sötétkék (of relatively high frequency in list task) and sötétszürke, világosszürke, sötétzöld, világoszöld and türkiz (frequent recurrence in the colour-naming task).

The combined analysis of the results of two surveys was carried out with the help of the same methods as in case of basic colour terms of Estonian (Sutrop 2000a; 2002).

We will sum up for every colour name the criterion threshold, which it superseded. In the colour-naming task, the thresholds to be reckoned with are frequency $(\mathrm{Fr}>20)$ and the mean position $(\mathrm{mP}<8)$. In the colournaming task the thresholds to be reckoned with are aggregate frequency (TotalFr $\geq 60$ ), dominance index (DI $1 / 2 \geq 1$ ) and specificity index (SI > 0.30 ). On the basis of those criteria the number of thresholds the colour names have superseded may range from 0 to 5 . The number of thresholds superseded is indicated by Table 6 , column $(\Sigma)$. In respect of superseding of at least one threshold the following colour terms will continue running for the status of basic name: piros, kék, zöld, sárga, fehér, fekete, lila, barna, szürke, rózsaszín, narancssárga, sötétbarna and bordó. No thresholds have been superseded by the following colour terms: vörös, narancs, citromsárga, világoskék, sötétkék, sötétszürke, világosszürke, sötétzöld, világoszöld and türkiz. Hence it stands proved that in Hungarian, running for the status of basic colour term is only one colour word designating 'red' piros, while orange is designated by narancssárga, not narancs.

Table 6

Summary of the results of the dominant terms in the tile naming task and for the most frequent terms in the list task. Fr - frequency, $\mathrm{mP}$ - mean position, DI - dominance index, SI - specificity index

\begin{tabular}{|c|c|c|c|c|c|c|c|}
\hline \multirow[t]{2}{*}{ Term } & \multirow[t]{2}{*}{ Gloss } & \multicolumn{2}{|c|}{ List task } & \multicolumn{3}{|c|}{ Colour tile naming task } & \multirow{2}{*}{$\underset{\Sigma}{\operatorname{Sum}}$} \\
\hline & & Fr $>20$ & $\mathrm{mP}<8$ & Fr $\geq 60$ & DI $1 / 2 \geq 1$ & $\mathrm{SI}>0,30$ & \\
\hline fekete & black & + & + & + & + & + & 5 \\
\hline fehér & white & + & + & - & + & + & 4 \\
\hline piros & red & + & + & + & + & + & 5 \\
\hline zöld & green & + & + & + & + & + & 5 \\
\hline sárga & yellow & + & + & - & - & + & 3 \\
\hline kék & blue & + & + & + & + & - & 4 \\
\hline barna & brown & + & - & + & + & - & 3 \\
\hline lila & purple & + & - & + & + & - & 3 \\
\hline narancs-sárga & orange & + & - & + & + & + & 4 \\
\hline rózsa-szím & pink & + & - & + & - & - & 2 \\
\hline szürke & grey & + & - & + & + & + & 4 \\
\hline sötét-barna & dark brown & - & - & + & + & + & 3 \\
\hline vörös & red & - & - & - & - & - & 0 \\
\hline narancs & orange & - & - & - & - & - & 0 \\
\hline bordó & bordeaux & + & - & - & - & - & 1 \\
\hline sötét-szürke & dark grey & - & - & - & - & - & 0 \\
\hline világos-szürke & light grey & - & - & - & - & - & 0 \\
\hline
\end{tabular}




\begin{tabular}{llcccccc} 
Term & Gloss & \multicolumn{2}{c}{ List task } & \multicolumn{2}{c}{ Colour tile naming task } & Sum \\
& & Fr $>\mathbf{2 0}$ & $\mathbf{m P}<\mathbf{8}$ & Fr $\geq \mathbf{6 0}$ & DI 1/2 $\geq \mathbf{1}$ & SI $>\mathbf{0 , 3 0}$ & $\Sigma$ \\
sötét-zöld & dark green & - & - & - & - & - & 0 \\
világos-zöld & light green & - & - & - & - & - & 0 \\
sötét-kék & dark blue & - & - & - & - & - & 0 \\
világos-kék & light blue & - & - & - & - & - & 0 \\
citrom-sárga & lemon yellow & - & - & - & - & - & 0 \\
türkiz & turquoise & - & - & - & - & - & 0
\end{tabular}

The excluded colour terms did not supersede any thresholds. Consequently, the name crossing only one threshold can run for the basic colour term. For us, such a colour term is bordó. By definition, it is plausible to doubt whether the colour name can be held a basic colour terms, if it is a late loan word. Colour term bordó has been derived from the place name Bordeaux and features in its present form in the Hungarian texts starting from 1897. On the strength of that we may omit it from among the candidates for the status of basic colour terms (nevertheless, a century is a sufficiently long period for a loan word to assimilate). Besides, bordó is the candidate for basic colour terms only after the list task, where it could have replaced the old colour name vörös (provided vörös and bordó altogether designate the same colour). In that case the colour term bordó has moved, in the Hungarian colour concepts system to the place previously occupied by vörös. The similar substitution has also occurred in French, where the old colour term brun 'brown' is being gradually ousted by the new colour name marron '(chestnut) brown' (cf. Des Lauriers 1992).

Now there are 12 more colour names running for the status of basic colour terms, in addition to standard names also sötétbarna 'dark brown'. The colour term sötétbarna exceeds in the colour-naming tasks all thresholds and obtains the sum of crossed thresholds 3. Sötétbarna 50\% domination $3(!)$ at colour tile (O-S3, RO-S3 and R-S3) is a very strong argument for basic status. The counterarguments are the following. Under the definition the basic name must be mono-lexemic, i.e. its meaning should not derive from the components of the name. Components of the colour name sötétbarna suggest that it designates dark and brown (by colour tile it is obvious, that the colour has a reddish hue, because the name dominates in orange reddish region). We might take into consideration the additional criterion of Berlin and Kay definition: if the status of the colour name is doubtful, its morphological intricacy should be taken into account. Because it is a compound word, sötétbarna will be dropped off the basic colour terms.

The most salient names in Hungarian are piros, fekete and zöld (exceeding all 5 prescribed thresholds). Following are those superseding 4 thresholds fehér and kék and surprisingly, this line includes also the so-called secondary basic colour terms szürke and narancssárga. In this connection we may ascertain that narancssárga designating orange is a basic colour word taken root in literary Hungarian and hence we may assert that the basic colour name may also be a compound word.

The basic colour names superseding 3 thresholds sárga, barna and lila. Colour term sárga does not cross two colour-naming task thresholds, because lacking was such colour tile, which $50 \%$ of the interviewees (DI $1 / 2$ ) would have called with the name sárga. The response of only one 
subject fell short (it was named 19 times, not 20 times), which would have given the $1 / 2$ dominance index.

Only 2 thresholds (frequency list task and aggregate frequency colournaming task) were crossed by the colour term rózsaszín. Evidently, in case of that colour word, in evidence is the lowest status basic colour terms candidate. Yet we may say that rózsaszín is the basic colour term, because the list task places it by cognitive salience index in the 10th place, before narancssárga. The colour-naming task however lacked consensus with respect to colour, which could be designated in Hungarian by the word rózsaszín. Most of all, 17 times, this name was assigned to colour tile R-T4, 13 times the same name was assigned to colour tile ROR-T3. There are valid reasons to assume that the term designating 'pink' rózsaszin 'the colour of rose' is associating also the colour of the cabbage rose (Rosa centifolia).

Consequently the Hungarian language has 11 basic colour terms piros, kék, zöld, sárga, fehér, fekete, lila, barna, szürke, narancssárga and rózsaszín (Table 7). The 12th basic name vörös offered by B. Berlin and P. Kay, is by no means a basic colour word of Hungarian. In the first place, its naming frequency was very low in list task, and in the second place, there was no whatsoever consensus of opinions, which colour might be vörös in the colour-naming tasks.

Table 7

Basic colour terms of Hungarian after B. Berlin and P. Kay (1969) and our study

B. Berlin and P. Kay (1969)

fejér
fekete
piros
vörös
zöld
sárga
kék
barna
lila
rózsaszín
narancs
szürke

$\begin{array}{ll}\text { Our study } & \text { English gloss } \\ \text { fehér } & \text { white } \\ \text { fekete } & \text { black } \\ \text { piros } & \text { red }_{(1)} \\ - & \text { red }_{2} \\ \text { zöld } & \text { green } \\ \text { sárga } & \text { yellow } \\ \text { kék } & \text { blue } \\ \text { barna } & \text { brown } \\ \text { lila } & \text { purple } \\ \text { rózsaszín } & \text { pink } \\ \text { narancssárga } & \text { orange } \\ \text { szürke } & \text { grey }\end{array}$

The Hungarian language meets fully and exclusively the last, the seventh stadium of Berlin-Kay development scheme. The second basic colour term vörös for 'red' offered by B. Berlin and P. Kay is, under this research, by no means the basic colour term of Hungarian. In the first place, its naming frequency was very low in list task, and in the second place, there was no whatsoever consensus of opinions, which colour might be vörös in the colour-naming tasks. This result coincides with the opinion of Robert E. MacLaury and his colleagues that the Hungarian piros is basic word and vöros is not (1997).

Secondly, in the modern Hungarian the name for 'white' (fehér) differs from that offered by B. Berlin and P. Kay (fejér). The difference may evidently 
be accounted for by the vernacular of B. Berlin and P. Kay's emigrant subject and the specificities of the dictionary they had at their disposal. Thirdly, B. Berlin and P. Kay have a different name for 'orange'. The Hungarian narancs means also the fruit orange and narancs-sárga is orange-yellow. Evidently, this difference is also due to the emigrants' language use. For instance regarding the Russian emigrants in the USA, one has referred to the assimilation of use of Russian colour terms with those of English (Andrews 1994). In English orange means both the fruit and the colour.

In his inspiring paper, Ferenc Kiefer (2005) recently asked: "Is there such thing as Hungarian semantics?". Among other examples he also discussed the basic colour terms and concluded that Hungarian semantic does exist just like Hungarian phonology, morphology and syntax do. In this paper our task is not to analyse the semantics of Hungarian colour terms, but we are in opinion that the puzzle of two Hungarian terms for red - the basic piros and non-basic vörös - is a semantic one and has nothing to do with the theory of basic colour terms. The semantic use of two colour terms for red in Hungarian (syntagmatic and paradigmatic) could be an areal phenomenon because a similar use of two terms for red - červená and rudá - can also be found (at least) in Czech.

\section{Summary}

In the list task and the colour-naming tasks 40 subjects offered altogether 3432 Hungarian colour names. Among them there were 595 different colour names. In the list task 858 colour names were offered, of which different were 205 . In the colour-naming task 40 subjects assigned to 65 colour tiles altogether 2574 colour names, of which 520 different names. In 26 cases the colour tile was not assigned a name. In the list task the subjects offered, among others 76 colour names, which did not occur in the later performed colour-naming task. In the colour-naming task there were 399 new colour names offered, which did not feature in the list task. Curiously 40 Hungarian subjects named altogether 595 different colour names, 80 Estonian subjects have however offered 759 different colour names (Sutrop 2000a).

Hungarian has 11 basic colour terms: piros 'red', kék 'blue', zöld 'green', sárga 'yellow', fehér 'white', fekete 'black', lila 'purple', barna 'brown', szürke 'grey', rózsaszín 'pink' and narancssárga 'orange'. Colour term vörös 'red ${ }_{2}$ ' is not a basic colour term in Hungarian. The Hungarian language meets fully and exclusively the last, the seventh stadium of Berlin-Kay development scheme.

The Davies-Corbett' field method used in this work was easy to master and efficient. The results on different languages obtained by that method could be compared. The cognitive salience index places in sequence the basic colour terms and it was in good correlation with combined analysis of the results of the list task and the colour-naming task.

\section{Acknowledgements}

We thank Dr. Ants Pihlak for translating our manuscript into English. The study was partly supported by the Estonian Science Foundation Grant Nos. 5040 and 6744 . 
Addresses:

Mari Uusküla

Institute of the Estonian Language and

University of Tartu

E-mail: Mari.Uuskyla@eki.ee

Phone: +372 6442406

Urmas Sutrop

Institute of the Estonian Language and

University of Tartu

E-mail: Urmas.Sutrop@eki.ee

Phone: +372 6449843 (+372 7376508)

\section{R E F E R E N C E S}

A n d re w s, D. R. 1994, The Russian Color Categories sinij and goluboj. An Experimental Analysis of Their Interpretation in the Standard and Emigré Languages. - Journal of Slavic Linguistics 2, 9-28.

B a r r a t t, L. B., K o n t r a, M. 1996, Matching Hungarian and English Color Terms. - International Journal of Lexicography 9, 102-117.

B a r t h a, K. 1937, Szókincstanulmány a magyar nyelv színelnevezéseiról, Debrecen (Dolgozatok a Debreceni Tiszta István Tudományegyetem magyar nyelvészeti szemináriumából 2).

B e r 1 i n, B., K a y, P. 1969, Basic Color Terms. Their Universality and Evolution, Berkeley.

C s a p ó d i, I. 1899, Vörös és piros. - Magyar Nyelvór 28, 201-204.

D a vi e s, I., C o r b e t t, G. 1994, The Basic Color Terms of Russian. Linguistics 32, 65-89.

- $\quad 1995$, A Practical Field Method for Identifying Basic Colour Terms. Languages of the World 9, 25-36.

D e s L a u ri e r s, H. du Bois 1972, Secondaire ou fundamental? Du statut indécis de certains termes de coleur en Français. - Meta 37, 331-341.

F o r b e s, I., K i s s, G. 1999, Colour Categorization and Naming in French and Hungarian. - Language and Parole in Synchronic and Diachronic Perspective, Amsterdam-Lausanne-New York-Oxford-Shannon-Singapore-Tokyo.

F l e t c h e r, R. 1980, The City University Colour Vision Test, London.

Gá r d o n y i, J. 1920, Piros vagy vörös. - MNy 16, 4-6, 84-87.

$\mathrm{K}$ i e f e r, F. 2005, Van-e magyar jelentéstan? - MNy 101, 2, 129-140.

K i s s, G., F o r b e s, I. 2001, Piros, vörös - red, rot, rouge. - Kontrasztív szemantikai kutatások, Szegéd (Segédkönyvek a Nyelvészet Tanulmányozásához 11), 190-199.

M a c L a u ry, R. E., A $1 \mathrm{~m}$ á s i, J., K öv e c s e s, Z. 1997, Hungarian piros and vörös. Color from Points of View. - Semiotica 114, 67-81.

M á t r a y, F. 1910, A magyar színelnevezésekról, Kalocsa.

M o s s, A. E. 1989, Basic Colour Terms. Problems and hypotheses. - Lingua $78,313-320$.

S e l é n y i, P. 1947, Piros és veres. - Magyar Nyelvór 72, 2, 12-14.

S u t r o p, U. 2000a, The Basic Colour Terms of Estonian. - Trames 4, 143168.

2000b, Basic Terms and Basic Vocabulary. - Estonian: Typological Studies IV, Tartu (Tartu Ülikooli eesti keele õppetooli toimetised 14), 118-145.

2001, List Task and a Cognitive Salience Index. - Field Methods 13, 263276.

2002, The Vocabulary of Sense Perception in Estonian. Structure and History, Frankfurt am Main-Berlin-Bern-Bruxelles-New York-OxfordWien (Opuscula Fenno-Ugrica Gottingensia 8).

W i e r z b i c k a, A. 1996, Semantics. Primes and Universals, Oxford-New York. 
МАРИ УУСКЮЛА, УРМАС СУТРОП (Таллинн)

\section{ПРЕДВАРИТЕЛЬНОЕ ИССЛЕДОВАНИЕ БАЗОВЫХ ТЕРМИНОВ ДЛЯ ОБОЗНАЧЕНИЯ ЦВЕТОВ В СОВРЕМЕННОМ ВЕНГЕРСКОМ ЯЗЫКЕ}

Б. Берлин и П. Кей в своей весьма обстоятельной монографии «Базовые цветообозначения» (1969) пришли к заключению, что в венгерском языке используется 12 (вместо 11) базовых цветообозначений. Свое предположение они аргументировали тем, что для названия красного цвета существуют два основополагающих термина - pirös и vörös. Однако наше эмпирическое исследование показало, что в современном венгерском языке для названия цветов используется именно 11 базовых терминов. Их когнитивная значимость приведена в известном указателе, предложенном У. Сутропом (2001), установлен следующий порядок: piros 'красный', kék 'голубой', zöld 'зеленый', sárga 'желтый', fehér 'белый', fekete 'черный', lila 'фриолетовый', barna 'коричневый', szürke'серый', rózsaszín 'розовый', narancssárga 'оранжевый'. Другой термин для красного цвета vörös не входит в число базовых цветообозначений. В венгерском языке базовые обозначения цветов кодируются универсальным способом. 